\title{
Seasonal and diel variation in North Atlantic right whale up-calls: implications for management and conservation in the northwestern Atlantic Ocean
}

\author{
Sarah E. Mussoline ${ }^{1,4, *}$, Denise Risch ${ }^{1}$, Leila T. Hatch ${ }^{2}$, Mason T. Weinrich ${ }^{3}$, \\ David N. Wiley ${ }^{2}$, Michael A. Thompson ${ }^{2}$, Peter J. Corkeron ${ }^{1}$, Sofie M. Van Parijs ${ }^{1}$ \\ ${ }^{1}$ Northeast Fisheries Science Center, Woods Hole, Massachusetts 02543, USA \\ ${ }^{2}$ Stellwagen Bank National Marine Sanctuary, Scituate, Massachusetts 02066, USA \\ ${ }^{3}$ The Whale Center of New England, Gloucester, Massachusetts 01930, USA \\ ${ }^{4}$ Present address: Biology Department, MS \#33, Woods Hole Oceanographic Institution, Redfield 256, Woods Hole, \\ Massachusetts 02543, USA
}

\begin{abstract}
Ship strikes are a major cause of anthropogenic mortality for the endangered North Atlantic right whale Eubalaena glacialis. Year-round data on animal presence are critical to managing ship strike mortality. Marine autonomous recording units were deployed throughout the Stellwagen Bank National Marine Sanctuary (SBNMS, Massachusetts Bay, USA) for 13 mo from January 2006 to February 2007 and on Jeffreys Ledge (JL, Gulf of Maine, USA) for 7 mo from November 2004 to May 2005 to determine whether passive acoustic monitoring (PAM) can improve information on right whale occurrence. Automated detection and manual review were used to determine presence and absence of right whale up-calls. In SBNMS, up-calls were detected year round, except during July and August, and calling rates were highest from January through May, peaking in April. In JL, up-calls occurred throughout all recording months, with the highest numbers from November through February. Up-calls were heard extensively in the wintertime throughout SBNMS and JL, suggesting that these areas are important overwintering grounds for right whales. Additionally, up-calls showed a strong diel trend in both areas, with significantly more calls occurring during twilight than dark and light periods. These data indicate that right whales are present more often and over longer time periods in the western Gulf of Maine than previously thought using conventional visual techniques. Finally, this study demonstrates the utility of PAM in providing a detailed and long-term picture of right whale presence in an area that poses a significant risk of anthropogenic mortality.
\end{abstract}

KEY WORDS: North Atlantic right whale ' Passive acoustic monitoring · Up-calls ' Seasonality · Diel variation · Stellwagen Bank National Marine Sanctuary · Jeffreys Ledge · Conservation

\section{INTRODUCTION}

Cetaceans are highly adapted for producing and perceiving sound underwater, and they use sound to communicate, navigate, and find food. Therefore, from the standpoint of management and conserva- tion, passive acoustic monitoring (PAM) is an effective tool for assessing and monitoring cetacean (and anthropogenic) activity across a variety of spatial and temporal scales. Examples of applications that demonstrate the value of PAM include: (1) detecting the presence of animals in areas where few or no sur- 
vey data are available; (2) assessing the predictability and variability of animal distribution patterns in areas of high human use; and (3) verifying and supplementing animal occurrence data from visual surveys (Mellinger et al. 2007, Van Parijs et al. 2009, Clark et al. 2010). This information, in combination with data from other existing technologies (e.g. shipboard/visual surveys and environmental sampling), can be used to develop measures to reduce anthropogenic sources of marine mammal mortality.

The North Atlantic right whale Eubalaena glacialis is the most endangered large whale population in the Atlantic (Clapham et al. 1999). As a result of historic whaling, ship collisions, and entanglements in fishing gear, fewer than 500 individuals exist today in the western North Atlantic (Knowlton \& Kraus 2001, Pettis 2009). In addition, ships and right whales co-occur throughout their entire migratory route as they move $2240 \mathrm{~km}$ between 5 major geographic regions: southeast coast of the United States, Great South Channel, Massachusetts Bay, Bay of Fundy, and Scotian Shelf (e.g. Winn et al. 1986, Kenney et al. 2001). The distribution of right whales is well documented in these main habitats, but less is known about their movement patterns elsewhere, particularly during the fall and winter months (Kraus et al. 1986, Mate et al. 1997, Weinrich et al. 2000). Such information is crucial for identifying areas and time periods in which concentrations of whales are present in order to reduce the likelihood of anthropogenic mortality events.

During the winter, primarily juveniles and pregnant females migrate to the coastal southeast US calving grounds off Georgia and Florida (Kraus et al. 1986, Winn et al. 1986). However, for portions of the population, specifically males and non-pregnant females, movements are unknown. Limited visual and boat-based surveys suggest that a large portion of the right whale population may remain in waters off the northeast USA during the winter in areas ranging from the Stellwagen Bank National Marine Sanctuary (SBNMS) to the northern Scotian Shelf (Weinrich et al. 2000, Mellinger et al. 2007, Cole et al. 2009).

Most information on right whale distribution and occurrence has been based on visual sightings, but PAM tools are increasingly being applied to augment these surveys. Unlike vessel-based or aerial efforts, passive acoustic devices can operate continuously in adverse weather and all light conditions, and can survey remote areas over long time scales (e.g. Moore et al. 2006, Mellinger et al. 2007). Current limitations of PAM, however, include labor-intensive analysis, sub- jectivity of species classification, limited knowledge of associated gender and behavior of callers, development of reliable automated call detectors, and missing calls due to silent animals (Mellinger et al. 2007, Baumgartner \& Mussoline 2011).

To date, several studies have used PAM techniques to investigate the characteristics of North Atlantic right whale vocalizations, including calling rates, frequency range of calls, and source levels (e.g. Matthews et al. 2001, Vanderlaan et al. 2003, Parks \& Tyack 2005, Clark et al. 2007). Based on previous studies of both Southern right whale Eubalaena australis and North Atlantic right whale vocalizations (Clark 1982, Parks et al. 2005), right whale calls have been broadly divided into 3 main categories: blow, broadband, and tonal sounds. The current study focuses on the occurrence patterns of a particular tonal sound, the up-call, which is produced by all age and sex classes and is thought to serve as a contact call (Parks \& Clark 2007). The up-call lasts approximately $1 \mathrm{~s}$ and is frequency modulated, typically increasing from 50 to $200 \mathrm{~Hz}$ (Clark 1982). While right whales are known to frequently use this call throughout most of the western Gulf of Maine (Van Parijs et al. 2009), to date no published data exist on its long-term temporal and diel occurrence patterns for the region.

SBNMS is a $2191 \mathrm{~km}^{2}$ submarine plateau, located at the mouth of Massachusetts Bay, and each year serves as a seasonal feeding area for one-third of the North Atlantic population of right whales (US Office of National Marine Sanctuaries 2007). To the northeast of SBNMS, Jeffreys Ledge (JL) is a $54 \mathrm{~km}$ long glacial deposit that has been irregularly surveyed by aerial and shipboard platforms. Together, SBNMS and JL make up a significant portion of the western part of the Gulf of Maine and North Atlantic right whale habitat. Due to the close proximity of the ports of Boston and Gloucester, the area is burdened by heavy boat traffic (WardGeiger et al. 2005, Hatch et al. 2008) and fishing activity (Wiley et al. 2003), and thus constitutes a high-risk area for right whales in terms of fishing gear entanglement, ship strike, and acoustic disturbance (Kraus 1990, Knowlton \& Kraus 2001, Laist et al. 2001, Parks et al. 2007, 2009).

We conducted long-term near-continuous archival PAM of right whale up-calls in SBNMS and JL. The aim of the study was to highlight the importance of PAM to improve knowledge on seasonal and diel occurrence of an endangered species, ultimately in hopes of informing management and conservation decisions in such a high-risk area. 


\section{MATERIALS AND METHODS}

\section{Acoustic data collection}

Marine autonomous recording units (MARUs) were deployed for 3 mo at a time throughout SBNMS at seafloor depths ranging from 41 to $76 \mathrm{~m}$ and on JL at depths ranging from 58 to $87 \mathrm{~m}$ (Fig. 1). Each MARU was comprised of an external hydrophone attached to a glass sphere containing batteries, computer electronics, and internal memory (Calpuca et al. 2000, Clark et al. 2002, Clark \& Clapham 2004). The units were moored $\sim 2 \mathrm{~m}$ above the ocean floor with sandbags and were acoustically triggered to release for surface retrieval. The units recorded continuously with a sampling rate of $2000 \mathrm{~Hz}$ and 12-bit resolution. The hydrophone frequency response was $-151.2 \mathrm{~dB}$ re $1 \mu \mathrm{Pa}$ from 10 to $585 \mathrm{~Hz}$, which encompasses the band of right whale up-calls. In SBNMS, MARUs were deployed from 5 January to 24 May
2006 and from 1 July 2006 to 27 February 2007 (13 mo in total) at 10 separate locations spaced about $15 \mathrm{~km}$ apart (Fig. 1). Instruments were not deployed during the month of June due to heavy bottom trawling activity in the area. In JL, MARUs were deployed from 1 November 2004 to 31 May $2005(7 \mathrm{mo})$ at 4 separate locations spaced 17 to $24 \mathrm{~km}$ apart (Fig. 1). As a result of occasional MARU mechanical failure and/or a MARU trawling event, between 6 and 9 MARUs (SBNMS) and 2 and 4 MARUs (JL) were available for analysis each month (Table 1). Deployment locations in SBNMS were selected to maximize acoustic coverage, and deployment dates were selected to determine year-round right whale presence. Deployment locations in JL were selected based on prior visual sighting information (Weinrich et al. 2005), and deployment dates were selected to determine right whale presence throughout the winter months. Successive deployments were made in approximately the same locations.

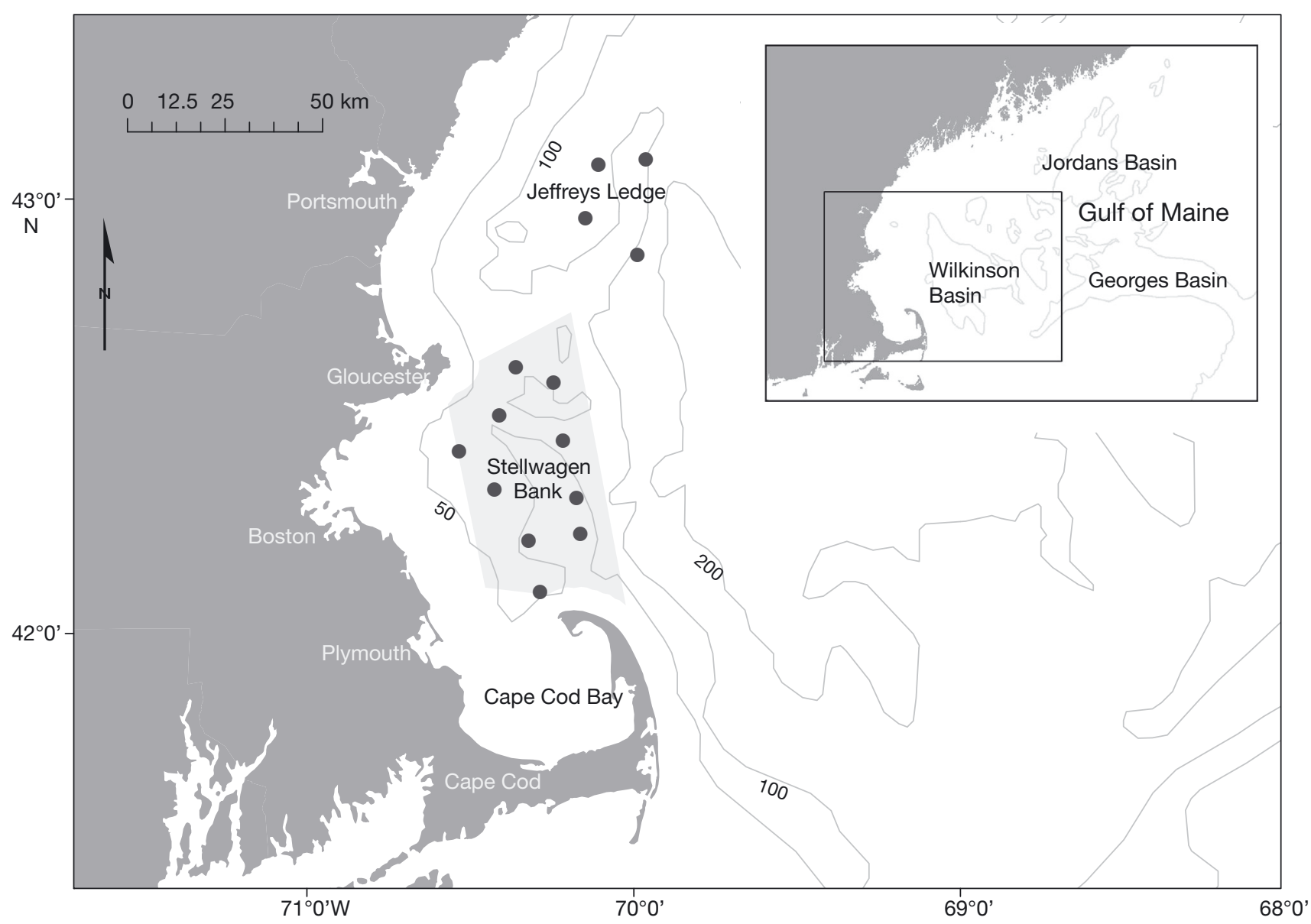

Fig. 1. Study area, depicting Stellwagen Bank National Marine Sanctuary and Jeffreys Ledge (Gulf of Maine, USA), with black circles indicating the deployment sites of marine automated recording units. Specifics on sampling effort are given in Table 1 
Table 1. Summary of the number of marine automated recording units available for analysis from each month for Stellwagen Bank National Marine Sanctuary (SBNMS) and Jeffreys Ledge (JL). Blank cells represent no effort

\begin{tabular}{|c|c|c|c|c|}
\hline \multirow{2}{*}{ Month } & \multicolumn{2}{|c|}{- SBNMS - } & \multicolumn{2}{|c|}{$-\mathrm{JL}$} \\
\hline & 2006 & 2007 & 2004 & 2005 \\
\hline January & 7 & 6 & & 4 \\
\hline February & 7 & 6 & & 4 \\
\hline March & 7 & & & 4 \\
\hline April & 9 & & & 2 \\
\hline May & 9 & & & 2 \\
\hline \multicolumn{5}{|l|}{ June } \\
\hline July & 8 & & & \\
\hline August & 8 & & & \\
\hline September & 7 & & & \\
\hline October & 7 & & & \\
\hline November & 7 & & 2 & \\
\hline December & 6 & & 4 & \\
\hline
\end{tabular}

\section{Area of detection}

According to data collected in SBNMS during a recent project, the average source level of right whale up-calls in this area is $165 \pm 3.5 \mathrm{~dB}$ root-mean-square re $1 \mu \mathrm{Pa}$ (Clark et al. 2008-2010). Using these data and acoustic propagation loss models constructed for SBNMS, maximum detection distances for right whale up-calls likely ranged from 8.7 to $15.7 \mathrm{~km}$ (see Clark et al. 2009, L. T. Hatch et al. unpubl.). Based on this information, it is possible that some up-calls were detected on more than 1 MARU when whale calls were intense and/or animals were equidistant from multiple recording units, resulting in an overestimate of the total number of calls. However, given that MARU separation was between 15 and $24 \mathrm{~km}$ (see 'Acoustic data collection'), this error should be small and should not have changed the general seasonal and diel trends observed in our data.

\section{Acoustic analyses}

Acoustic data were analyzed using the eXtensible BioAcoustic Tool (XBAT; Figueroa 2008) written in MATLAB (The Mathworks). The resulting $89280 \mathrm{~h}$ of acoustic recordings for SBNMS and $16642 \mathrm{~h}$ for JL were analyzed with an automated call detection algorithm that was specifically designed to detect relatively stereotyped up-calls in varying ambient noise conditions (Urazghildiiev \& Clark 2006, Urazghildiiev et al. 2008). All automated detections were reviewed by an experienced analyst to remove false positives from the dataset. In addition, $26 \mathrm{~d}$ cho- sen for varying levels of ambient noise, were manually hand-browsed to calculate the rate of missed calls.

Automatic and manual detection methods for right whale up-calls are known to produce errors when humpback whale Megaptera novaeangliae sounds are present, as this species can produce upsweeps that closely resemble right whale up-calls. Therefore, a protocol was established to maximize discrimination between the sounds from these 2 species. The degree of overlap between the 2 species was most problematic in April to May and October to December 2006, during the periods of highest occurrence of recorded humpback whale song (Vu et al. 2012). In cases when humpback whale upsweeps were present, the browsing window duration was lengthened from 30 to $240 \mathrm{~s}$ to determine the presence of other humpback whale sounds. Three to $5 \mathrm{~min}$ of the recording before and after the questionable detection were browsed to determine whether the upsweep was part of the repetitive humpback whale sound pattern, and whether that sound was also of similar amplitude to the humpback sound pattern. If so, the upsweep would subsequently be attributed to humpback whales. We used these criteria because humpback whale song consists of repetitive phrases (Payne \& McVay 1971), and their social sounds during migration can occur in a series of fairly stereotyped calls (Dunlop et al. 2007). Both songs and calls include a variety of different frequencymodulated sound types that typically have stronger harmonics than right whale up-calls (Mellinger et al. 2007, Munger et al. 2008). In contrast, right whale upcalls or other call types rarely occur in sequences, and when they do, they typically occur in bouts with longer and less regular inter-call intervals than humpbacks (Matthews et al. 2001, Vanderlaan et al. 2003, Mellinger et al. 2011). Thus, by careful aural and visual analysis, we made conservative distinctions between the 2 species, and subsequently excluded any uncertain calls from the analysis.

\section{Descriptive and statistical analyses}

For both SBNMS and JL, right whale up-call presence was examined for seasonal and diel patterns. Due to the differences in deployment years between SBNMS and JL, comparisons were made within study sites to avoid confounding the results with interannual changes. To explore seasonality, we report the average number of up-calls from all MARUs, normalized by the number of MARUs that were recording each day. 
We also analyzed diel patterns in right whale upcalling. Diel patterns were examined using 24hourly time periods based on local time, and days for which no calls were detected were excluded from the analysis. To correct for variability in call rates over time scales greater than $1 \mathrm{~d}$, we calculated and plotted an hourly mean adjusted calling rate by subtracting the mean number of calls calculated for a $24 \mathrm{~h}$ period from each hourly call rate within that same $24 \mathrm{~h}$ period. For each day with calls, we obtained the maximum altitude of the sun relative to the earth's horizon using data from the US Naval Observatory Astronomical Applications website (http://aa.usno.navy.mil) for $42^{\circ} 09^{\prime} \mathrm{N}$ and $71^{\circ} 52^{\prime} \mathrm{W}$. Call detections were then categorized

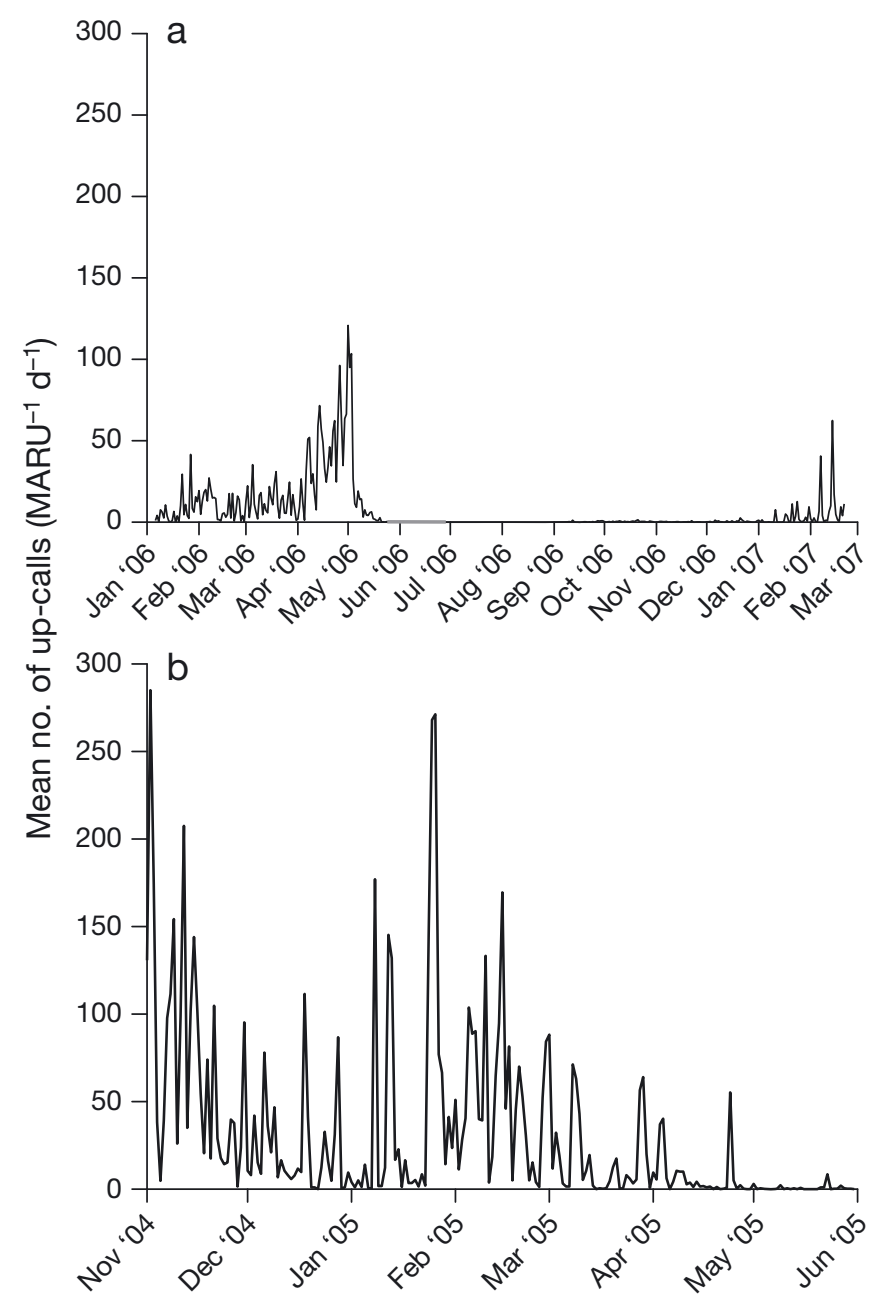

Fig. 2. Eubalaena glacialis. Mean number of right whale upcalls per marine automated recording unit (MARU) detected per day in (a) Stellwagen Bank National Marine Sanctuary from January 2006 to February 2007 (with no effort in June 2006) and (b) Jeffreys Ledge during the months of November 2004 to May 2005 into 3 light regimes: twilight (includes both dawn and dusk, where sun altitude was between -12 and $0^{\circ}$ ), light (where sun altitude was $>0^{\circ}$ ), or dark (where sun altitude was $<-12^{\circ}$ ). Because our data were not normally distributed, we used a nonparametric Kruskal-Wallis test to evaluate whether calling rates (calls $\mathrm{h}^{-1}$ ) differed across the 3 light regimes.

\section{RESULTS}

\section{Up-call detections}

There were a total of 366 recording days (93\% of deployment days) for SBNMS and 213 recording days (100\% of deployment days) for JL. SBNMS and JL are areas subject to heavy bottom trawling fishing activity; therefore, most of the gaps in the data represent days when MARUs were trawled. Right whale up-calls were detected at both locations. In total, 21223 up-calls were automatically detected and human-verified for SBNMS, as were 26988 up-calls for JL. The missed up-call rate for the chosen detector threshold varied from 7 to $19 \%$, with a higher rate during March, April, and May (12 to 19\%), when large numbers of right whales were present in SBNMS. Conversely, false positives were caused by calls from other species of marine mammals (i.e. humpback whales) and/or other anthropogenic and biological noise events, and were removed by manually reviewing all detection results (see 'Materials and methods').

\section{Seasonal patterns}

In SBNMS, right whale up-call rates varied over the 13 mo period. Up-call rates increased from January to March, showing a strong seasonal pattern with a peak in April, followed by a decrease towards the end of May. No up-calls were detected in July and August, and few up-calls were detected from September to December (Fig. 2a). In JL, the rate of right whale up-calls varied across the 7 mo recording period. The number of up-calls reached a maximum in November, with secondary maxima from January through February, after which call rates gradually decreased from March through May (Fig. 2b). Overall, right whale up-call rates peaked during late fall/winter in JL (285 calls MARU ${ }^{-1} \mathrm{~d}^{-1}$ in November) and in the spring in SBNMS (120 calls MARU ${ }^{-1} \mathrm{~d}^{-1}$ in April). 


\section{Diel patterns}

Diel patterns were observed in right whale upcalling in both SBNMS and JL. Over the $24 \mathrm{~h}$ period, hourly mean adjusted calling rates were higher during twilight and dark hours in SBNMS and during twilight in JL, with reduced up-calling observed during light hours (Fig. 3). Over the 3 light regimes (dark, twilight, light), hourly mean adjusted upcalling rates were significantly different in both SBNMS (Kruskal-Wallis test: $\chi^{2}=7.23, \mathrm{df}=2, \mathrm{p}<$ 0.0269; Fig. 4a) and JL (Kruskal-Wallis test: $\chi^{2}=$ 15.39, df $=2, p<0.0005$; Fig. 4b), with increased upcalling at twilight. In SBNMS, the hourly mean adjusted up-calling rates and their associated SE for

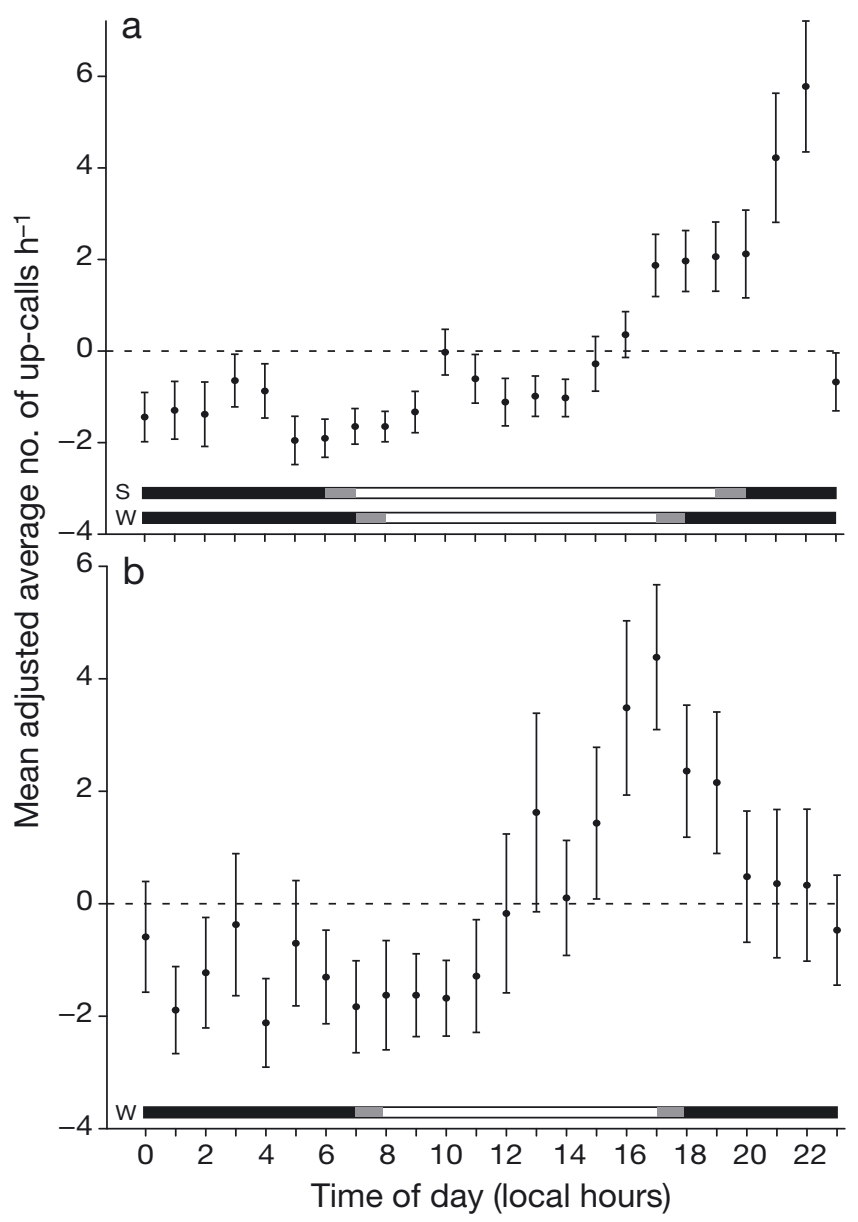

Fig. 3. Eubalaena glacialis. Mean \pm SE adjusted number of up-calls per hour for (a) Stellwagen Bank National Marine Sanctuary (SBNMS) during the months of January 2006 to February 2007 (with a data gap in June 2006) and (b) Jeffreys Ledge (JL) during the months of November 2004 to May 2005. Horizontal bars at the bottom of the plot show light (white), twilight (grey), and dark (black) hours during the summer (s) and winter (w) solstices in SBNMS and winter solstice in JL

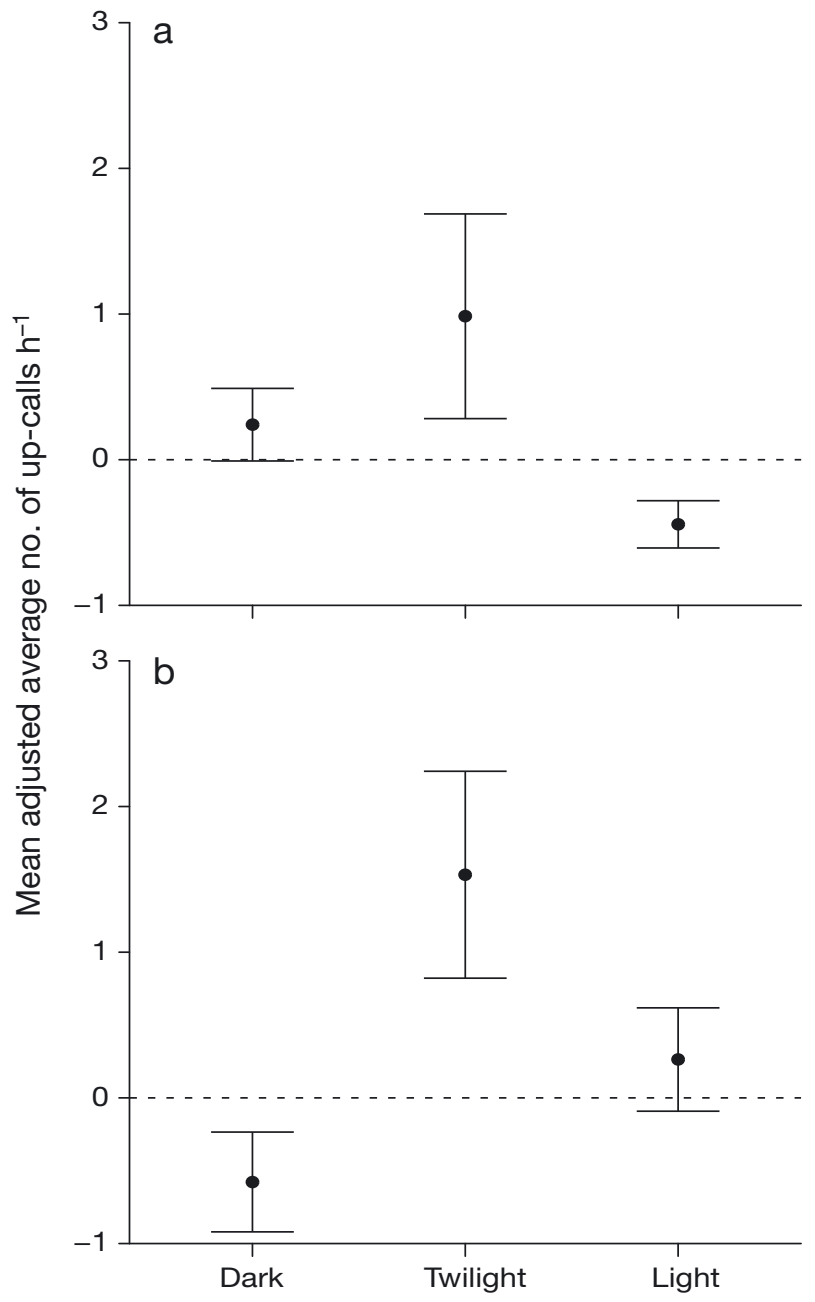

Fig. 4. Eubalaena glacialis. Hourly mean \pm SE adjusted number of up-calls recorded during each light regime: dark, twilight, and light for (a) Stellwagen Bank National Marine Sanctuary and (b) Jeffreys Ledge

each light regime over $208 \mathrm{~d}$ were: $0.24 \pm 0.25$ (dark), $0.98 \pm 0.70$ (twilight), $-0.44 \pm 0.16$ (light). In JL, the hourly mean adjusted up-calling rates for each light regime over $185 \mathrm{~d}$ were: $-0.58 \pm 0.34$ (dark), $1.53 \pm$ 0.71 (twilight), $0.26 \pm 0.35$ (light). While the hourly mean adjusted calling rates (Fig. 3) offered a finer resolution of diel trends than the hourly mean adjusted light regime averages (Fig. 4), both analyses demonstrate an increase in up-call presence during twilight hours.

\section{DISCUSSION}

Knowledge of seasonal and diel variation in species presence is required to define when management or mitigation measures should be heightened 
or may not be necessary at all. This study attempted to assess right whale up-call distribution patterns in 2 NW Atlantic habitats: SBNMS and JL.

\section{Up-call detections}

It is important to recognize that changes in an observed up-calling rate may be due to an increase/ decrease in the total number of calling whales within the detection range, an increase/decrease in individual calling rates, or both. These considerations are especially important if the goal of a study is to derive occurrence and abundance patterns from long-term acoustic data collected over larger spatial scales. While on a daily temporal resolution there seems to be no association between visual counts of animals from aerial surveys and acoustic calling rates (Clark et al. 2010), our results suggest that scaling to a seasonal temporal resolution can reveal broad-scale patterns of right whale occurrence that associate well with visual data records. For example, comparing the relative number of up-calls recorded in SBNMS during the high call count period in April to May to those recorded in the low call count period in August to September, reveals a pattern of acoustic occurrence that matches the pattern of right whale abundance estimated from aerial surveys, with high abundance of right whales in spring and low abundance in late summer (Cole et al. 2007).

\section{Seasonal patterns}

Right whale up-calls were present throughout SBNMS in all recording months of the year except July and August, and were present in JL throughout the entire recording period. The variations in patterns over shorter time periods could be a reflection of vocalizing animals moving in and out of the area, and/or of seasonal changes in behaviors associated with up-call production. However, we presume that long time periods of silence, as observed with the cessation of right whale calling in July and August in SBNMS, most likely indicate that right whales were no longer present in the study area. The most notable observation, however, is the persistence of right whale up-calling during winter months, indicating the presence of at least some animals during a period when a part of this population (mostly adult females, mother/calf pairs, and juveniles), are traditionally thought to winter in southern latitudes (Kraus et al. 1986, Winn et al. 1986, Kenney et al. 2001).
The location of a possible wintering ground for the remaining portion of the North Atlantic right whale population that does not migrate south is unknown. However, its geographic location is most likely driven by prey availability and/or mating opportunities. Aerial survey data from November and January 2004 to 2007 found high proportions of sexually mature right whales present west of Jordan's Basin (northeast of JL; Fig. 1), providing evidence for a possible midwinter mating ground (Cole et al. 2009). In addition, visual surveys confirmed high numbers and occurrence of right whales on JL from October to December 2004 (Weinrich et al. 2005). The persistent wintertime calling revealed in this study supplements the visual surveys and could be an implication of delayed migration or that some individuals may forego a southward migration altogether during some years. This finding underscores the utility of PAM, particularly to aid in the search for right whales in regions and times of the year where they are believed to occur infrequently. Continued research, including visual, acoustic, and oceanographic sampling efforts, will help provide insight into the behavioral significance of right whale up-calling beyond the known context of establishing and maintaining acoustic contact. In the long term, the integrated interpretation of such multi-modal data might be able to explain why some whales remain in Gulf of Maine habitats during winter. More importantly, identifying and protecting these seasonal habitats may become critical for the protection of the North Atlantic right whale population. For example, known seasonal distribution patterns of right whales have already influenced the realignment of the shipping lanes into the Port of Boston and Grand Manan Basin in the Bay of Fundy (Hatch et al. 2008, Vanderlaan et al. 2008), as well as the implementation of vessel speed restriction at certain times of year along the east coast of the US Atlantic seaboard (NMFS 2008). Thus far, the distribution of acoustic detections in the area surrounding the Boston Traffic Separation Scheme appears to agree with the distribution of visual detections, providing additional support for the lane shift (Hatch et al. 2008). However, larger-scale and longer-term comparisons of vessel traffic patterns in concert with acoustic detection information will be necessary to assess whether additional routing measures within and around SBNMS and JL could further decrease collision risk.

\section{Diel patterns}

The diel cycle of up-calls illustrates that the time of day when whales are most vocal (twilight hours) does 
not necessarily coincide with daylight. The upcalling rates of many baleen whales show diel periodicity and in some cases may be driven by prey distribution (e.g. Stafford et al. 2005, Wiggins et al. 2005, Baumgartner \& Frantantoni 2008, Munger et al. 2008). The primary prey of the North Atlantic right whale is the 2 to $3 \mathrm{~mm}$ calanoid copepod Calanus finmarchicus (Wishner et al. 1995, Baumgartner \& Mate 2003), a zooplankton known to exhibit diel vertical migration (e.g. Zaret \& Suffern 1976, Baumgartner et al. 2011). Our current understanding of how right whales locate and communicate about prey patches on such large spatial scales is relatively limited (Kenney et al. 2001). During crepuscular periods, as their prey becomes diffuse, high up-calling rates may be inversely related to foraging intensity, and may be triggered by changes in behavioral context, group composition, and/or number of animals present.

While more information is needed to deduce what the observed diel pattern means, knowing that the pattern exists is important when devising management and mitigation strategies that are based on PAM. For example, if data were sampled on a duty cycle, the choice of the cycle might be influenced by this diel pattern. In order to understand why right whales up-call more at night in SBNMS and JL, we need to investigate the behavioral significance and the environmental context in which certain call types are made. Contrary to our results, Mellinger et al. (2007) found an increase in up-calling during daylight hours on the Scotian Shelf, suggesting that diel trends may be site specific. Longer time series across the species' known habitats are needed to obtain a better understanding of call usage and to determine what call types are the most appropriate to use at different times of the day (and year) for indicating right whale presence using PAM.

\section{CONCLUSIONS}

Understanding and predicting right whale distribution is pertinent to management decisions (i.e. critical habitat designations, exclusion areas, speed restrictions, and gear modifications) in order to reduce anthropogenic-related right whale deaths. The passive acoustic recordings analyzed in this study showed that (1) right whales are present in the Gulf of Maine area more frequently and for longer periods of time than previously thought (i.e. some remaining through winter), and (2) right whales in this area produce more up-calls during twilight periods than during other times. To further improve the use of acoustics as an effective monitoring tool, more information is needed on how up-calling patterns vary with behavior, group size, age or sex class, season, and between different regions of the NW Atlantic. Similarly, in order to evaluate the detection efficiency of the up-call in these areas, it is important to understand how right whales use other call types. Additional analysis is required to determine whether the observed seasonal and diel trends are representative of other years, and additional acoustic data will supplement these findings and help elucidate interannual trends. Despite a clear need to better understand North Atlantic right whale acoustic ecology, given the highly endangered status of this species, the detection of even a single call can be informative for management decisions. Furthermore, the results described here demonstrate that PAM provides a more complete assessment of this rare species in regions and at times of the day and year where traditional surveys are ineffective.

Acknowledgements. Funding for this study was provided by NOAA's Northeast Fisheries Science Center, Northeast Regional Office, and NOAA's Stellwagen Bank National Marine Sanctuary. We are indebted to the following people for assistance both in the field and in the laboratory: $T$. Calupca, R. Dickey, J. Kiernan, W. Krkoska, C. Pekarcik, D. Ponirakis, A. Rhoads, K. Sardi Sampson, C. TessegliaHymes, C. Tremblay, and A. Warde. We thank the 3 anonymous reviewers for commenting on earlier drafts of this manuscript, as well as C. Clark who played a key role as an external non-official reviewer. Finally, we are particularly grateful for the invaluable support provided by M. Baumgartner, N. Lysiak, K. Stafford, and E. Vu.

\section{LITERATURE CITED}

Baumgartner MF, Frantantoni DM (2008) Diel periodicity in both sei whale vocalization rates and the vertical migration of their copepod prey observed from ocean gliders. Limnol Oceanogr 53:2197-2209

> Baumgartner MF, Mate BR (2003) Summertime foraging ecology of North Atlantic right whales. Mar Ecol Prog Ser 264:123-135

$>$ Baumgartner MF, Mussoline SEM (2011) A generalized baleen whale call detection and classification system. J Acoust Soc Am 129:2889-2902

Baumgartner MF, Lysiak NSJ, Schuman C, Urban-Rich J, Wenzel FW (2011) Diel vertical migration behavior of Calanus finmarchicus and its influence on right and sei whale occurrence. Mar Ecol Prog Ser 423:167-184

Calpuca TA, Fistrup KM, Clark CW (2000) A compact digital recording system for autonomous bioacoustic monitoring. J Acoust Soc Am 108:2582

> Clapham PJ, Young SB, Brownell RL Jr (1999) Baleen whales: conservation issues and the status of the most endangered populations. Mammal Rev 29:37-62

> Clark CW (1982) The acoustic repertoire of the southern right whale, a quantitative analysis. Anim Behav 30: 1060-1071 
Clark CW, Clapham PH (2004) Acoustic monitoring on a humpback whale (Megaptera novaeangliae) feeding ground shows continual singing into late spring. Proc R Soc Lond B Biol Sci 271:1051-1057

Clark CW, Borsani JF, Notabartolo di Sciara G (2002) Vocal activity of fin whales Balaenoptera physalus, in the Ligurian Sea. Mar Mamm Sci 18:286-295

Clark CW, Gillespie D, Nowacek DP, Parks SE (2007) Listening to their world: acoustics for monitoring and protecting right whales in an urbanized ocean. In: Kraus SD, Rolland RM (eds) The urban whale. Harvard University, Cambridge, MA, p 333-357

> Clark CW, Ellison WT, Southall BL, Hatch L, Van Parijs SM, Frankel A, Ponirakis D (2009) Acoustic masking in marine ecosystems: intuitions, analysis, and implication. Mar Ecol Prog Ser 395:201-222

> Clark CW, Brown MW, Corkeron P (2010) Visual and acoustic surveys for North Atlantic right whales, Eubalaena glacialis, in Cape Cod Bay, Massachusetts, 2001-2005: management implications. Mar Mamm Sci $26: 837-854$

Clark CW, Ellison WT, Hatch LT, Merrick RL, Van Parijs SM, Wiley DN (2008-2010) An ocean observing system for large-scale monitoring and mapping of noise throughout the Stellwagen Bank National Marine Sanctuary. Reports to the National Oceanographic Partnership Program, Award number: N00014-07-1-1029. Available at http://www.onr.navy.mil/reports/FY09/npclark.pdf

Cole TVN, Stimpert A, Pomfret L, Houle K, Niemeyer M (2007) North Atlantic right whale sighting survey (NARWSS) and right whale sighting advisory system (RWSAS) 2002 results summary. Ref Doc 07-18a. US Department of Commerce, Northeast Fisheries Science Center, Woods Hole, MA

Cole T, Glass A, Hamilton PK, Duley P and others (2009) Potential mating ground for North Atlantic right whales off the northeast USA. 18th Biennial Conference on the Biology of Marine Mammals, Quebec

Dunlop RA, Noad MJ, Cato DH, Stokes D (2007) The social vocalization repertoire of east Australian migrating humpback whales (Megaptera novaeangliae). J Acoust Soc Am 122:2893-2905

Figueroa H (2008) XBAT. v5. Cornell University Bioacoustics Research Program. Available at www.xbat.org (accessed August 2007)

> Hatch LT, Clark CW, Merrick R, Van Parijs SM and others (2008) Characterizing the relative contribution of large vessels to total ocean noise fields: a case study using the Gerry E. Studds Stellwagen Bank National Marine Sanctuary. Environ Manag 42:735-752

Kenney RD, Mayo CA, Winn HE (2001) Migration and foraging strategies at varying spatial scales in western North Atlantic right whales: a review of hypotheses. J Cetacean Res Manag 2:251-260

Knowlton AR, Kraus SD (2001) Mortality and serious injury of northern right whales (Eubalaena glacialis) in the western North Atlantic Ocean. J Cetacean Res Manag 2: 193-208

Kraus SD (1990) Rates and potential causes of mortality in North Atlantic right whales (Eubalaena glacialis). Mar Mamm Sci 6:278-291

Kraus SD, Prescott JH, Knowlton AR, Stone GS (1986) Migration and calving of right whales (Eubalaena glacialis) in the western North Atlantic. Rep Int Whaling Comm 10:139-144
Laist DW, Knowlton AR, Mead JG, Collet AS, Podesta M (2001) Collisions between ships and whales. Mar Mamm Sci 17:35-75

> Mate BA, Nieukirk SL, Kraus SD (1997) Satellite-monitored movements of the northern right whale. J Wildl Manag 61:1393-1405

Matthews JN, Brown S, Gillespie D, Johnson M and others (2001) Vocalisation rates of the North Atlantic right whale (Eubalaena glacialis). J Cetacean Res Manag 3: 271-282

Mellinger DK, Nieukirk SL, Matsumoto H, Heimlich SL, Dziak RP, Haxel J, Fowler M (2007) Seasonal occurrence of North Atlantic right whale (Eubalaena glacialis) vocalizations at two sites on the Scotian Shelf. Mar Mamm Sci 23:856-867

Mellinger DK, Nieukirk SL, Klinck K, Klinch H, Dziak RP, Clapham PJ, Brandsdóttir B (2011) Confirmation of right whales near a historic whaling ground east of Southern Greenland. Biol Lett 7:411-413

> Moore SE, Stafford KM, Mellinger DK, Hildebrand JA (2006) Listening for large whales in off-shore waters of Alaska. Bioscience 56:49-55

Munger LM, Wiggins SM, Moore SE, Hildebrand JA (2008) North Pacific right whale (Eubalaena japonica) seasonal and diel calling patterns from long-term acoustic recordings in the southeastern Bering Sea, 2000-2006. Mar Mamm Sci 24:795-814

NMFS (National Marine Fisheries Service) (2008) Final rule to implement speed restrictions to reduce the threat of ship collisions with North Atlantic right whales. Fed Regist 73:60173-60191

Parks SE, Clark CW (2007) Acoustic communication: social sounds and the potential impacts of noise. In: Kraus SD, Rolland RM (eds) The urban whale. Harvard University, Cambridge, MA, p 310-357

Parks SE, Tyack PL (2005) Sound production by North Atlantic right whales (Eubalaena glacialis) in surface active groups. J Acoust Soc Am 117:3297-3306

Parks SE, Hamilton PK, Kraus SC, Tyack PL (2005) The gunshot sound produced by male North Atlantic right whales (Eubalaena glacialis) and its potential function in reproductive advertisement. Mar Mamm Sci 21:458-475

Parks SE, Clark CW, Tyack PL (2007) Short- and long-term changes in right whale calling behavior: the potential effects of noise on acoustic communication. J Acoust Soc Am 122:3725-3731

Parks SE, Urazghildiiev I, Clark CW (2009) Variability in ambient noise levels and call parameters of North Atlantic right whales in three habitat areas. J Acoust Soc Am 125:1230-1239

Payne RS, McVay S (1971) Songs of humpback whales. Science 173:585-597

Pettis H (2009) North Atlantic Right Whale Consortium Annual Report Card (01 November 2007 - 30 April 2009). Scientific Committee Meeting Document SC/61/ BRG11. International Whaling Commission, Cambridge, MA

Stafford KM, Moore SE, Fox CG (2005) Diel variation in blue whale calls recorded in the eastern tropical Pacific. Anim Behav 69:951-958

US Office of National Marine Sanctuaries (2007) Gerry E. Studds Stellwagen Bank National Marine Sanctuary Condition Report. US Department of Commerce, National Oceanic and Atmospheric Administration, Silver Spring, MD 
Urazghildiiev IR, Clark CW (2006) Acoustic detection of North Atlantic right whale contact calls using the generalized likelihood ratio test. J Acoust Soc Am 120: 1956-1963

Urazghildiiev IR, Clark CW, Krein T (2008) Detection and recognition of North Atlantic right whale contact calls in the presence of ambient noise. Can Acoust 36:111-117

- Van Parijs SM, Clark CW, Sousa-Lima RS, Parks SE, Rankin S, Risch D, Van Opzeeland IC (2009) Management and research applications of real time and archival passive acoustic sensors over varying temporal and spatial scales. Mar Ecol Prog Ser 395:21-36

Vanderlaan ASM, Hay AE, Taggart CT (2003) Characterization of North Atlantic right whale (Eubalaena glacialis) sounds in the Bay of Fundy. IEEE J Oceanic Eng 28: 164-173

> Vanderlaan ASM, Taggart CT, Serdynska AR, Kenney RD, Brown MW (2008) Reducing the risk of lethal encounters: vessels and right whales in the Bay of Fundy and on the Scotian Shelf. Endang Species Res 4:283-297

Vu ET, Risch D, Clark CW, Gaylord S and others (in press) Humpback whale Megaptera novaeangliae song occurs extensively on feeding grounds in the western North Atlantic Ocean. Aquat Biol 14:175-183

> Ward-Geiger LI, Silber GK, Baumstark RD, Pulfer TL (2005) Characterization of ship traffic in right whale critical habitat. Coast Manag 33:263-278

> Weinrich MT, Kenney RD, Hamilton PK (2000) Right whales (Eubalaena glacialis) on Jeffreys Ledge: a

Editorial responsibility: Clive McMahon,

Darwin, Australia habitat of unrecognized importance? Mar Mamm Sci 16:326-337

Weinrich MT, Sardi K, Pekarcik C (2005) Fall boat-based surveys on Jeffreys Ledge for North Atlantic right whales distribution, abundance, behavior, ecology, photo-identification: a semi-annual report, September 1, 2004 March 1, 2005. Submitted in fulfillment of award number: NA04NMF4720401. The New England Whale Center of New England, Gloucester, MA

> Wiggins SM, Oleson EM, McDonald MA, Hildebrand JA (2005) Blue whale (Balaenoptera musculus) diel call patterns offshore of southern California. Aquat Mamm 31: 161-168

Wiley DN, Moller JC, Zilinskas K (2003) The distribution and density of commercial fisheries and baleen whales within the Stellwagen Bank National Marine Sanctuary: July 2001 - June 2002. Mar Technol Soc J 37:35-53

Winn HE, Price CA, Sorensen PW (1986) The distributional biology of the right whale (Eubalaena glacialis) in the western North Atlantic. Rep Int Whaling Comm 10(Spec Issue):129-138

- Wishner KF, Schoenherr JR, Beardsley R, Chen C (1995) Abundance, distribution and population structure of the copepod Calanus finmarchicus in a springtime right whale feeding area in the southwestern Gulf of Maine. Cont Shelf Res 15:475-507

> Zaret TM, Suffern JS (1976) Vertical migration in zooplankton as a predator avoidance mechanism. Limnol Oceanogr 21:804-813

Submitted: May 11, 2011; Accepted: December 19, 2011 Proofs received from author(s): March 3, 2012 